\title{
APLIKASI BIBLE PADA MOBILE PHONE DENGAN MENGGUNAKAN JAVA MICRO EDITION (JAVA ME)
}

\author{
Alexander Setiawan, Agustinus Noertjahyana, Eriek Tjung \\ Jurusan Teknik Informatika, Fakultas Teknologi Industri Universitas Kristen Petra \\ Jl. Siwalankerto 121 - 131 Surabaya 60236 Indonesia \\ Telp. (031)-2983455, Fax. (031)-8417658 \\ E-mail: alexander@peter.petra.ac.id, agust@peter.petra.ac.id,m26405133@john.petra.ac.id
}

\begin{abstract}
ABSTRAK: Alkitab merupakan buku pedoman hidup bagi kaum Kristiani, perkembangan teknologi ponsel memungkin untuk membuat aplikasi Alkitab pada mobile phone. Penelitian ini bertujuan untuk mengembangkan aplikasi Alkitab yang telah ada dengan memberikan fitur-fitur baru. Fitur-fitur tersebut diantaranya, yaitu dapat menampilkan dua jenis Alkitab bersamaan (Terjemahan Baru dan King James Version), fitur note untuk aplikasi bookmark, visibility yang jelas pada ayat yang di-bookmark, tampilan, pengelompokan pada bookmark dan pengelompokan hasil pencarian kata, aplikasi renungan harian, dan peta. Database Alkitab yang digunakan adalah database Go Bible, dan pencarian string menggunakan metode Turbo Boyer Moore. Pengujian terhadap aplikasi dilakukan pada Nokia N78, Sony Ericsson w910i, K800 sebagai sampel. Dari hasil pengujian, aplikasi yang telah dibuat dapat berjalan dengan baik pada ketiga ponsel tersebut.
\end{abstract}

Kata kunci: Alkitab, mobile phone, turbo boyer moore.

\begin{abstract}
The Bible is a guidebook for the Christian life, the development of mobile technology allows to create applications Bible on mobile phones. This research aims to develop applications of existing Bible by providing new features. These features include, that can display two types of the same Bible (New International Version and the King James Version), features of note to the bookmark application, clear visibility on the in-verse bookmarks, display, grouping the bookmarks and search results clustering words, the application daily devotional, and maps. Database Bible is a database used Go Bible, and the search string using the Turbo Boyer Moore. Tests on the application made on the Nokia N78, Sony Ericsson W910i, K800 as a sample. From the results of testing, applications have been made to run well on all three mobile phone.
\end{abstract}

Keywords: Bible, mobile phone, turbo boyer moore.

\section{PENDAHULUAN}

Dengan berkembangnya teknologi ponsel saat ini menjadikan ponsel tidak hanya berfungsi sebagai alat komunikasi saja, ponsel saat ini dilengkapi berbagai macam software. Teknologi ponsel yang akan masih terus berkembang mengubah ponsel yang semulanya hanyalah sebuah alat komunikasi menjadi sebuah device portable yang serba guna.

Dari perkembangan teknologi tersebut, beredar juga perangkat lunak Alkitab pada ponsel. Namun sayangnya, perangkat lunak Alkitab tersebut kurang mendapat perhatian. Oleh karena itu, maka pada kesempatan kali ini, Penulis memutuskan untuk mencoba memperbaiki dan menambahkan beberapa fitur yang belum tersedia pada aplikasi. Fitur tersebut antara lain memberikan highlight pada ayat, memberikan note, advanced search yang akan mempermudah user untuk mencari content pada Alkitab berdasakan inputan user, selain itu juga terdapat aplikasi renungan harian.
Dalam pembuatan aplikasi ini penulis menggunakan Java Micro Edition (Java ME). Java ME adalah salah satu dari tiga Java platform yang dikembangkan oleh SUN Microsystem pada aplikasi pada device berukuran kecil dalam arti memory dan CPU yang lebih kecil dibandingkan personal computer seperti handphone, two way pager, Personal Digital Assistant (PDA) dan lain sebagainya [1]. Java ME memiliki kelebihan jika dibandingkan dengan pemograman yang lain yaitu tidak bergantung pada sistem operasi dari ponsel yang bersangkutan asalkan ponsel tersebut mendukung Java. Hal ini sesuai dengan slogan dari Java write once run everywhere. Sehingga diharapkan aplikasi ini dapat digunakan oleh banyak orang [2].

\section{TINJUAN PUSTAKA}

\section{Java ME}

Java ME merupakan kombinasi antara Java API (sekumpulan interface Java) dan Java Virtual 
Machine (JVM) [3]. Java Micro Edition (Java ME) merupakan subset dari J2SE, oleh karena itu tidak semua library yang ada pada J2SE dapat digunakan pada Java ME. Tetapi Java ME memiliki beberapa library khusus yang tidak dimiliki J2SE. Teknologi Java ME juga memiliki keterbatasan, terutama jika aplikasi yang ada dijalankan pada handphone/PDA, bisa dari segi merk handphone/PDA, maupun kemampuan dan dukungan yang dimiliki perangkat tersebut.

Java ME pada dasarnya terdiri dari tiga buah bagian utama, yaitu configuration, profile, dan paketpaket opsional lainnya seperti Mobile Media API. Configuration dan profile sudah disediakan oleh perusahaan alat dan telah diletakkan di dalam alat bersangkutan sehingga telah siap digunakan [3]. Arsitektur dari Java ME dapat dilihat pada Gambar 1.

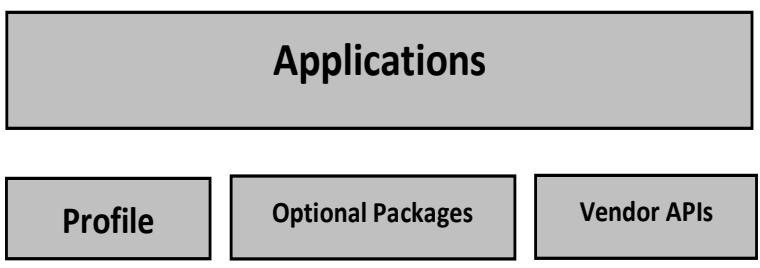

\section{Configuration}

Gambar 1. Arsitektur Java ME

Configuration merupakan bagian yang berisi JVM yang secara khusus didesain untuk alat, dan beberapa library kelas lainnya [4]. Terdapat 2 buah configuration, yaitu Connected Limited Device Configuration (CLDC) dan Connected Device Configuration (CDC). CLDC digunakan pada alat-alat kecil seperti handphone, PDA, maupun pager. Sedangkan CDC merupakan superset dari CLDC sehingga semua kelas yang didefinisikan di dalam CLDC akan ada juga di dalam CDC.

Pada bagian utama ketiga dari Java ME adalah paket-paket opsional, yang merupakan paket-paket tambahan yang dibutuhkan oleh aplikasi sehingga pada saat proses deployment paket-paket tersebut perlu didistribusikan juga sebagai bagian dari aplikasi bersangkutan. Paket-paket opsional ini bukan merupakan paket yang dibuat oleh perusahaan alat yang digunakan [3].

Aplikasi-aplikasi yang dibuat didalam handphone dengan menggunakan MIDP disebut dengan MIDlet. MIDlet berupa sebuah kelas abstrak yang merupakan sub kelas dari bentuk dasar aplikasi sehingga antarmuka aplikasi pada Java ME dan aplikasi manajemen pada perangkat lunak dapat terbentuk [4].

\section{ANALISIS DAN DESAIN SISTEM}

Pada saat penelitian dilakukan, aplikasi bible pada ponsel, khususnya yang berbasikan Java ME, dinilai sebagian orang masih kurang baik, maka perlu dilakukan perbaikan terutama di sisi fitur. Karena sistem yang akan dibuat menggunakan Java ME, maka penulis mengambil contoh aplikasi Go Bible versi 2.2.6 (http://gobible.jolon.org) yang telah banyak digunakan sebagai bahan untuk dianalisa.

Berikut adalah beberapa fitur yang telah ada dan menurut penulis perlu diperbaiki dan dikembangkan.

a) Satu aplikasi Go Bible hanya dapat menampilkan satu jenis Alkitab berbahasa tertentu dan versi tertentu misalkan Alkitab berbahasa Inggris versi King James ataupun Alkitab berbahasa Indonesia versi Terjemahan Baru.

b) Terdapat fitur Go To, yang dimana user dapat menampilkan ayat yang diinginkannya. Namun fitur tersebut kurang efisien dalam penggunaannya karena pada pemilihan jenis kitab, harus menekan tombol arah ke bawah dan arah ke atas pada ponsel sesuai dengan urutan kitab dari perjanjian lama sampai perjanjian baru.

c) Tedapat fitur search string pada kitab-kitab pada Alkitab. Aplikasi yang telah ada sudah cukup baik. Namun hasil tampilan dari search tersebut ditampilkan begitu saja. Ada baiknya jika hasil dari proses search tersebut dikelompokkan berdasarkan kitab, sehingga akan mempermudah user dalam mencari hasil searching.

d) Terdapat fitur add bookmark yang dimana user dapat menyimpan ayat-ayat yang dianggap user penting. Untuk melihat ayat-ayat mana saja yang di bookmark, user dapat melihatnya pada aplikasi show bookmarks. Namun, aplikasi ini tidak memberikan visibility pada ayat yang telah dicatat ke dalam bookmark. Sehingga user tidak dapat mengetahui dengan jelas ketika user membacanya bahwa ayat tersebut telah dibookmark selain masuk pada aplikasi bookmark tersebut. Selain itu perlu juga dibuat fitur untuk mengelompokkan ayat yang akan di bookmark berdasarkan nama kitab, pada aplikasi show bookmarks.

Berikut adalah fitur yang terdapat pada aplikasi yang akan dibuat:

1. Aplikasi yang dibuat dapat menampilkan 2 (jenis) Alkitab. File Alkitab yang digunakan adalah file GoBible. Penulis memilih file GoBible dikarenakan file GoBible terdiri dari ayat-ayat alkitab yang telah dipecah-pecah menjadi bagian-bagian kecil sehingga dalam pembacaan tidak memerlukan waktu proses yang lebih lama dan memiliki struktur file yang jelas. 
2. File GoBible memiliki 3 (tiga) file utama yang terletak pada folder "Bible Data" yaitu:

- GlobalFile Index

GlobaFileIndex yang terletak pada folder

"Bible Data/Index" GlobalFile Index memiliki struktur sebagai berikut:

Byte: Banyaknya kitab [Pengulangan sebanyak kitab]

- utf-Nama kita

- utf- Nama File kitab

- short-Pasal awal (Catatan: ada versi yang menggunakan byte)

- short- Jumlah pasal (Catatan: ada versi yang menggunakan byte)

- [Pengulangan untuk setiap pasal]

- byte-Berisikan nomer dari file yang berisikan pasal ini. Misalkan Kejadian 0 $(0=$ nomor $)$ yang berisikan data dari kejadian pasal pertama.

- int- Banyaknya karakter yang terkandung pada pasal ini

- byte -Banyaknya ayat pada pasal ini

- BookIndex File

BookIndex File terletak pada folder "Bible Data/[Book Name]/Index" [Lakukan Pengulangan sebanyak banyak pasal]

[Lakukan Pengulangan sebanyak banyak ayat] [short - banyaknya karakter yang terkandung pada ayat ini]

- VerseData File

VerseData File terletak pada folder "Bible Data/[Book Name]/[Book Name] [File Number]"

Int-Ukuran panjang data ayat-ayat yang terdapat pada file ini (dalam satuan byte bukan character) byte[-Berisikan data dari ayatayat yang terkandung di dalam file ini (dalam format UTF-8 byte).

3. Pada aplikasi go to yang dibuat, user dapat mengetikkan sendiri kitab yang ingin dituju sehingga menjadi praktis dan cepat.

4. Selain fitur search biasa (pencarian ayat berdasarkan string yang inputkan user) juga terdapat fitur advanced search seperti yang tertuang pada bab I, sub bab ruang lingkup.

5. Fitur bookmark, pada fitur ini user dapat memilih ayat - ayat mana saja yang dianggap penting serta memberikan catatan. Selain itu terdapat visibility yang jelas guna membedakan ayat mana yang telah di-bookmark dan yang mana yang tidak. Catatan tersebut tersebut disimpan pada sebuah Record Management System (RMS).

6. Terdapat aplikasi renungan harian. Sumber data yang digunakan adalah data renungan dari internet yang ditentukan sebelumnya
7. Terdapat fitur Short Message Service (SMS) yang dapat mengirimkan ayat tertentu ke nomor penerima.

8. Terdapat fitur peta yang menampilkan lokasi beberapa kejadian-kejadian pada Alkitab.

Secara garis besar desain arsitektur dari aplikasi yang dibuat dapat digambarkan seperti pada Gambar 2.

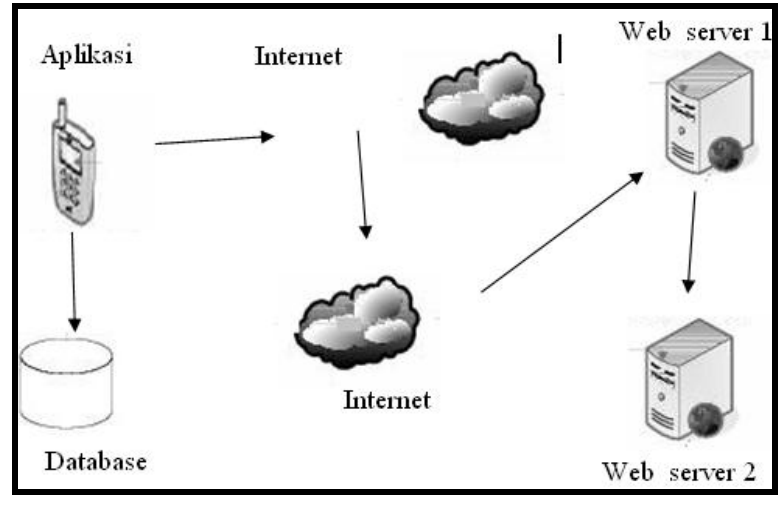

Gambar 2. Desain Arsitektur Aplikasi

Basisdata berupa file Alkitab GoBible yang terletak didalam aplikasi, seperti yang telah dijelaskan sebelumnya. Koneksi internet dilakukan pada saat user menjalankan fitur renungan harian, aplikasi akan memperoleh data dari web server 1 , kemudian dari web server 1 akan mengambil data dari web server 2 . Data yang diperoleh dari web server 2 akan disederhanakan dengan memisahkan konten-konten penting dengan konten yang tidak diperlukan yang kemudian dikirim ke aplikasi. Hal ini di lakukan untuk mengurangi pemakaian bandwith dari aplikasi. Desain sistem digambarkan dengan menggunakan UML dapat dilihat pada Gambar 3.

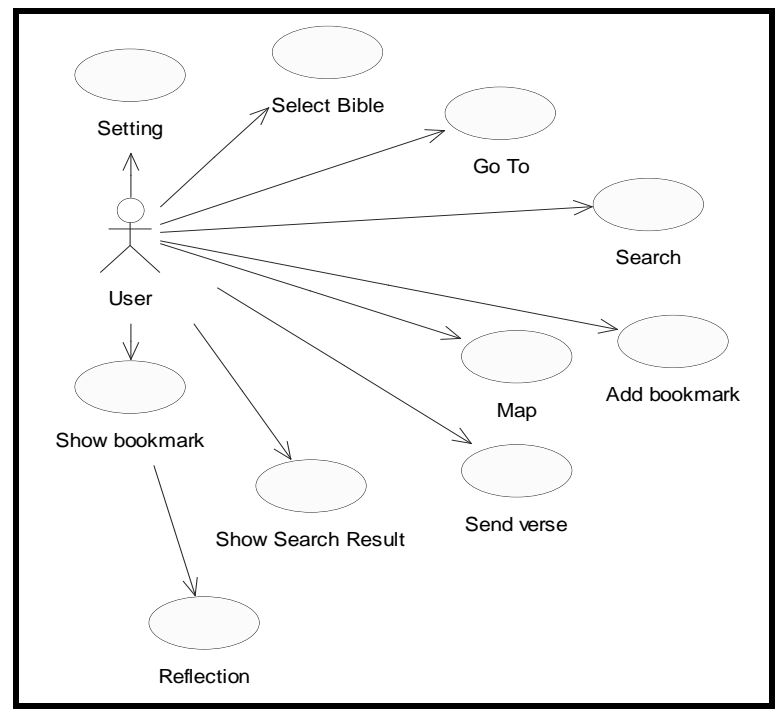

Gambar 3. Use Case Diagram Sistem Keseluruhan 
Gambar 3 menggambarkan use case diagram sistem secara keseluruhan yaitu:

1. Setting

Use case ini berfungsi untuk menunjukkan bahwa user dapat melakukan setting terhadap sistem aplikasi.

2. Select Bible

Use case ini berfungsi untuk menunjukkan bahwa user dapat memilih Alkitab yang ingin ditampilkan. Alkitab yang dapat ditampilkan dibatasi menjadi dua, yaitu:

- Terjemahaan Baru.

- King James Version.

3. Use case goto

Use case goto berfungsi untuk memberikan kemudahan kepada user untuk pindah pada ayatayat tertentu.

4. Use case search

Use case ini berfungsi untuk melakukan proses pencarian kata pada ayat ayat yang terdapat dalam Alkitab.

5. Use case add bookmark

Use case ini berfungsi untuk menyimpan ayat yang dianggap penting oleh user.
6. Use case map

Use case map berfungsi untuk menampilkan petapeta yang berhubungan dengan peristiwa pada Alkitab.

7. Use case send verse

Use case ini berfungi untuk mengirimkan pesan yang berisikan ayat tertentu. Pesan tersebut dikirimkan ke nomor tertentu melalui Short Message Service (SMS)

8. Use case show search result

Use case ini berfungsi untuk menampilkan hasil pencarian string terakhir kali.

9. Use case show bookmark

Use case ini berfungsi untuk menampilkan ayatayat yang telah di-bookmark. Selain menampilkan user juga dapat menghapus bookmark serta melakukan pengeditan terhadap catatan yang telah disimpan bersamaan dengan ayat yang telah dibookmark.

10. Use case reflection

Use case ini berfungsi untuk menampilkan bahan renungan tiap harinya.

\section{Gambar 4.}

Desain Class Diagram dapat dilihat pada

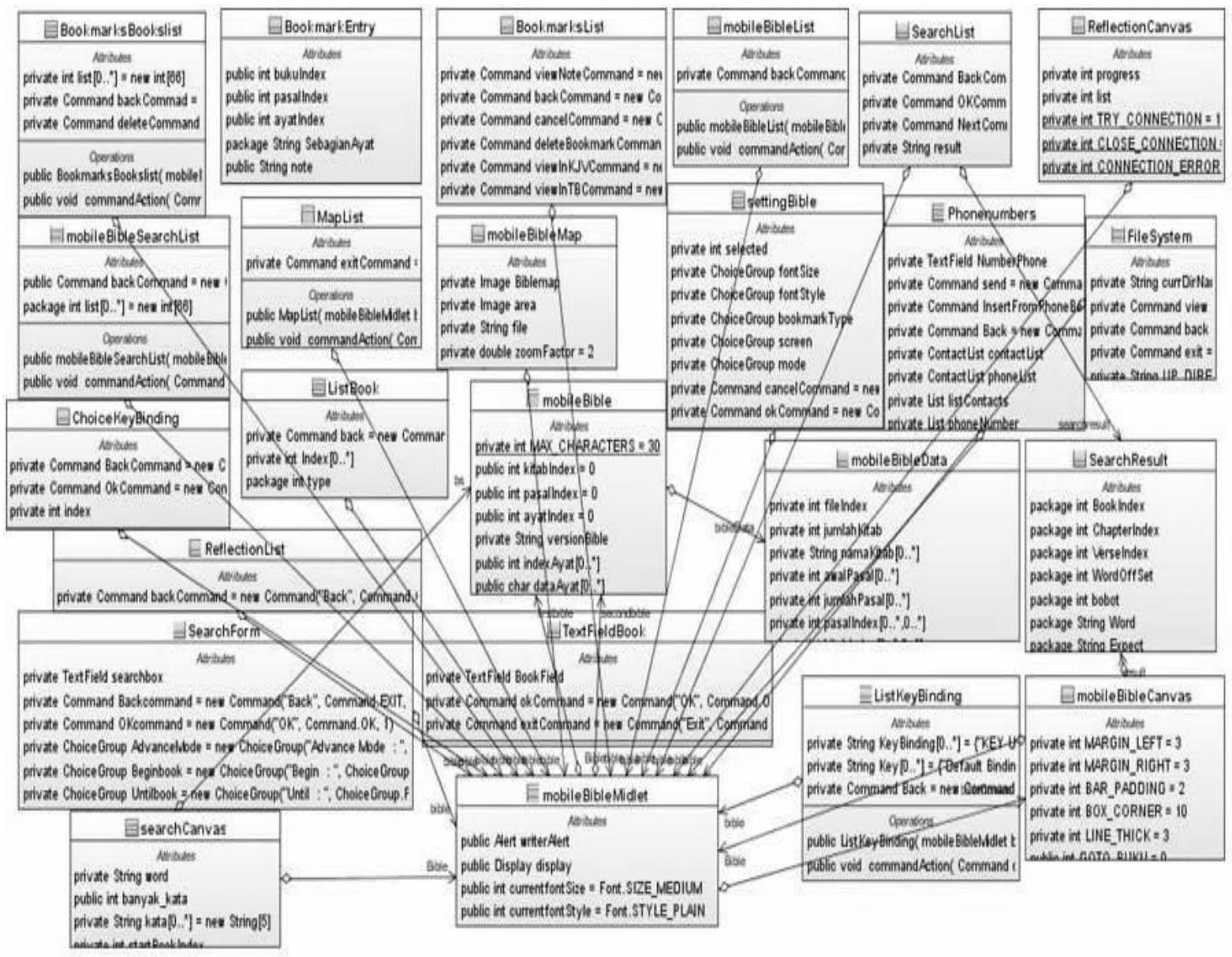

Gambar 4. Desain Class Diagram Aplikasi Bible 


\section{PENGUJIAN SISTEM}

Dalam pengujian aplikasi sistem ini dilakukan pengambilan sample handphone yang akan diuji cobakan, diantaranya adalah Nokia N78 dan Sony Ericsson K800. Adapun spesifikasi Nokia N 78 dapat dilihat pada Tabel 1, spesifikasi Sony Ericsson K800 dapat dilihat pada Tabel 2.

Tabel 1. Spesifikasi Nokia N78

\begin{tabular}{lll}
\hline Size & $\begin{array}{l}\text { Dimensi } \\
\text { Type }\end{array}$ & $\begin{array}{l}113 \times 49 \times 15,1 \mathrm{~mm}, 76.5 \mathrm{cc} \\
\text { TFT, } 16 \mathrm{M} \text { colors }\end{array}$ \\
\hline Display & Size & $\begin{array}{l}\text { 240 x 320 pixels, } \\
2,4 \text { inches } \\
\text { Touch- } \\
\text { sensitive Navi wheeingl }\end{array}$ \\
& & 76 MB storage, 96 MB RAM \\
\hline Memory & Internal & MIDP 2.0 \\
\hline Feature & Java & Symbian OS, S60 rel. 3.2 \\
& OS & ARM 11 369 MHz processor \\
\hline
\end{tabular}

Tabel 2. Spesifikasi Sony Ericsson K800

\begin{tabular}{lll}
\hline Size & Dimensi & $105 \times 47 \times 22 \mathrm{~mm}$ \\
\hline Display & Size & $240 \times 320$ pixels, \\
& & 2.0 inch, 30 x $40 \mathrm{~mm}$ \\
\hline Memory & Internal & $64 \mathrm{MB}$ \\
\hline Feature & Java & MIDP 2.0 Sony Ericsson \\
& OS & Sony Ericsson \\
& CPU & - \\
\hline
\end{tabular}

- Pengujian Tampilan Ayat pada Handphone

Nokia N78
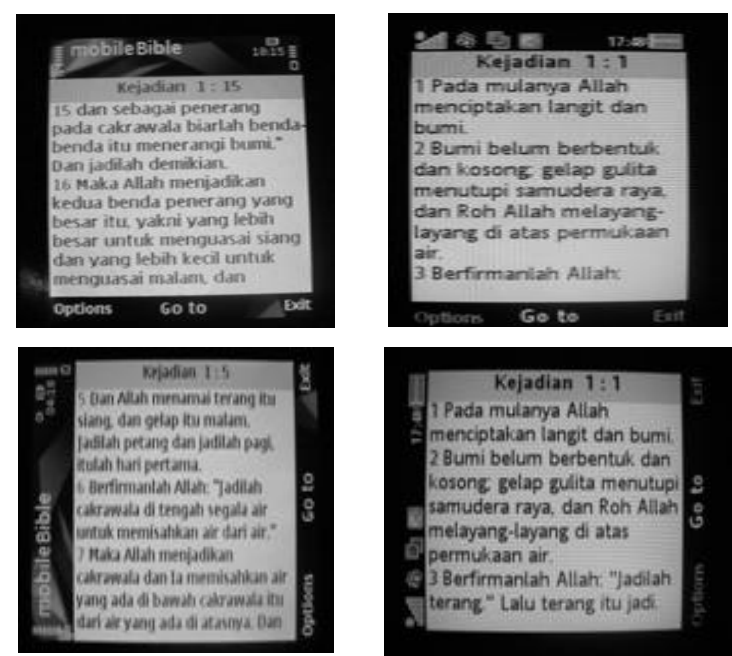

Gambar 5. Tampilan Pada Handphone Nokia N78 dan Sony Ericsson K800

Gambar 5 Menunjukan bahwa ayat-ayat pada Alkitab berhasil ditampilkan dengan baik pada Nokia N78 dan Sony Ericson K 800, baik itu ditampilkan secara vertikal ataupun horizontal.
- Pengujian Proses Normal Search dengan Range Pencarian Satu Kitab
Nokia N 78
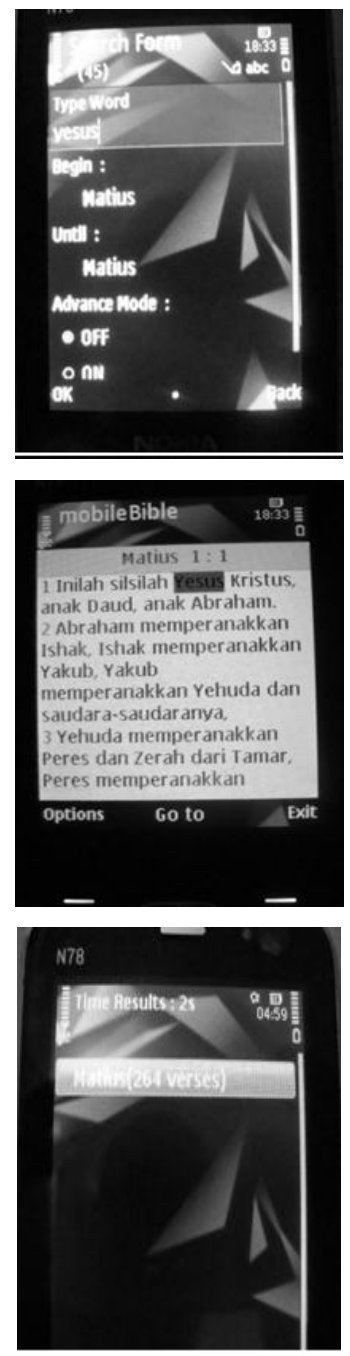

Sony Ericson K 800
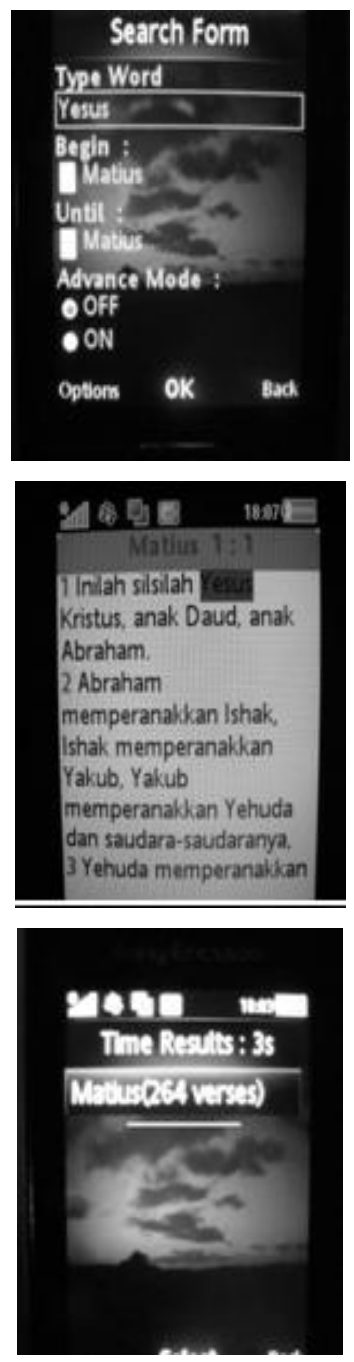

Gambar 6. Proses Searching String Salah satu Kitab pada Nokia N78 dan Sony Ericsson K800

Gambar 6 menunjukan bahwa aplikasi dapat melakukan task searching dengan baik dan dapat memberikan tanda kepada string yang yang dicari. Untuk waktu pencarian di seluruh kitab Matius, Nokia N78 memerlukan waktu \pm 2 detik, sedangkan pada Sony Ericsson K800 memerlukan waktu \pm 3 detik.

- Pengujian Proses Advanced Search

Gambar 7 menunjukan sistem dapat menjalankan task advanced searching dengan baik, baik itu pada Nokia N78 maupun Sony Ericsson K800, Hal ini dapat dilihat pada gambar diatas inputan "Yesus lahir" dapat dicari dan kemudian di hitung bobot relasi berdasarkan banyaknya kata inputan yang terdapat pada ayat tersebut. 


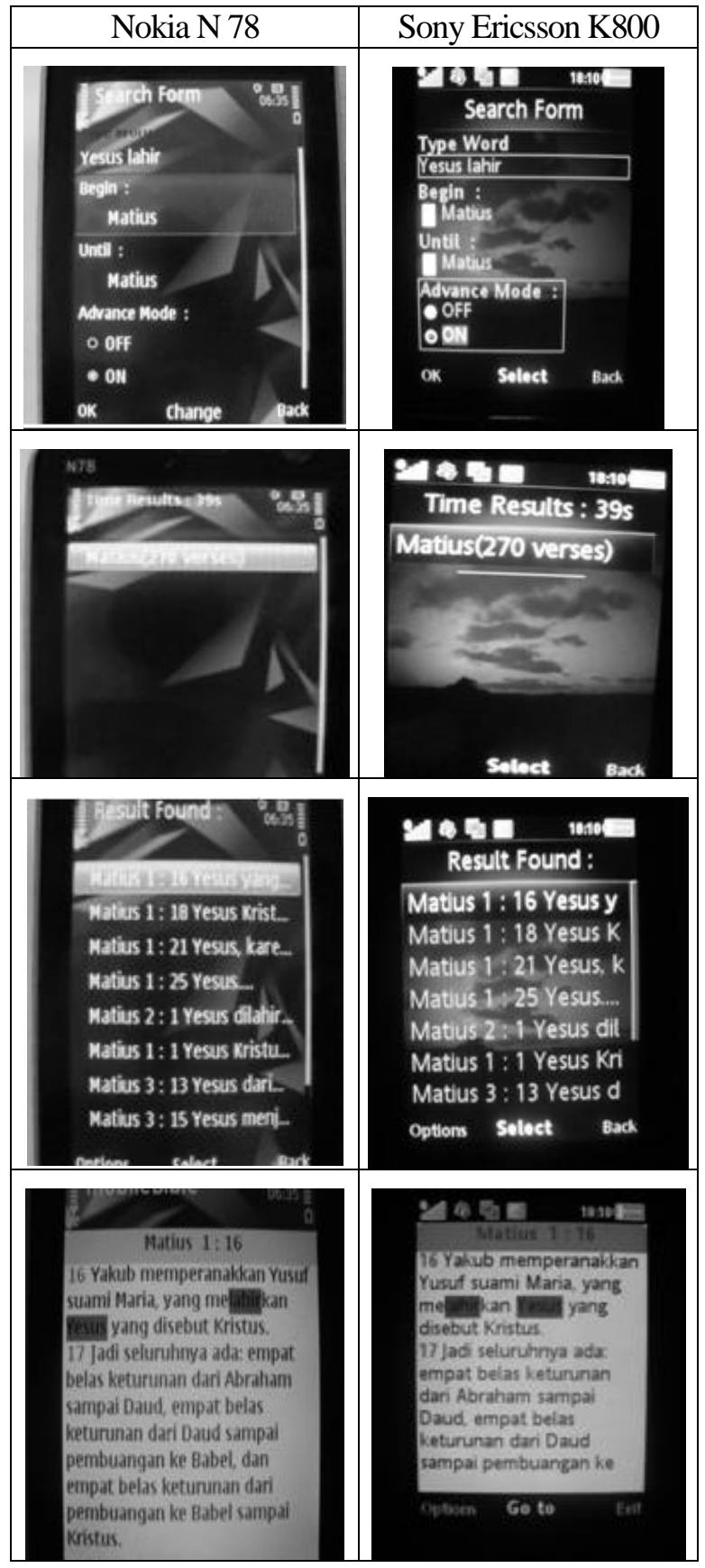

Gambar 7. Pengujian Advanced Search pada Nokia N78 dan Sony Erricson K800

- Pengujian Proses Normal Search dengan Range Pencarian lebih dari Satu Kitab

Gambar 8 menunjukan bahwa sistem dapat menjalankan task searching dengan baik pada range yang telah ditetapkan oleh user (lebih dari 1 kitab). Selain itu sistem mampu mengelompokan jumlah hasil pencarian berdasarkan nama kitab. Pengelompokan dilakukan untuk memudahkan user mencari ayat yang dituju. Untuk waktu pencarian Nokia N78 memerlukan waktu \pm 12 detik, sedangkan Sony Ericsson K800 memerlukan waktu \pm 28 detik.
Nokia N 78
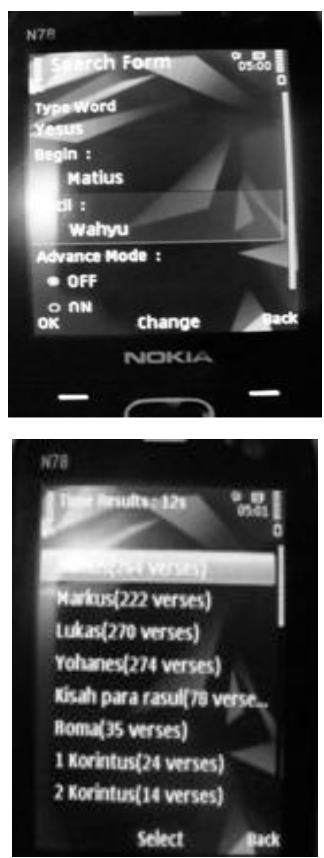

Sony Ericson K 800

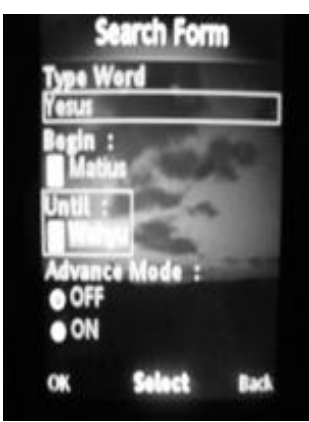

प्र०ण Time Results : 285

Matus(264 verses) Markus(222 verses) Lukas(270 verses) Yohanes(274 verses) Kisah para rasail $78 \mathrm{v}$ Roma(35 verses)

1 Korintus(24 verses) Solact exd.
Gambar 8. Proses Searching String dengan Range Beberapa Kitab (Matius-Wahyu) pada Nokia N78 dan Sony Ericsson K800

- Pengujian Tampilan Peta

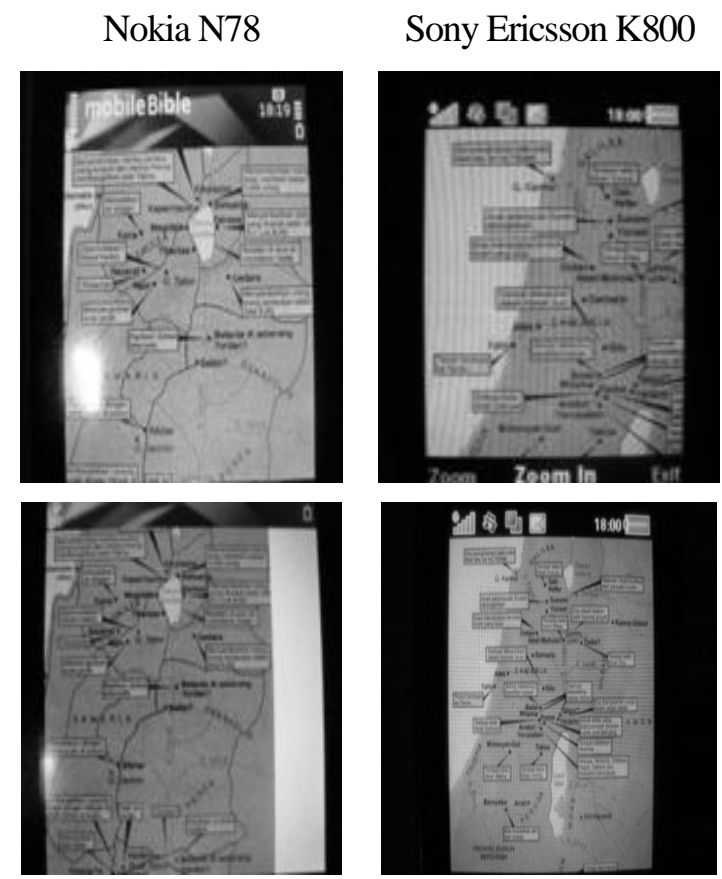

Gambar 9. Pengujian Tampilan Map pada Nokia N78 dan Sony Ericson K800

Gambar 9 menunjukkan sistem dapat menampilkan peta dengan baik pada Nokia N78 maupun Sony Erricson w910i, dan Sony Erricson k800, baik itu proses zoom in maupun zoom out. 
- Pengujian Renungan Harian

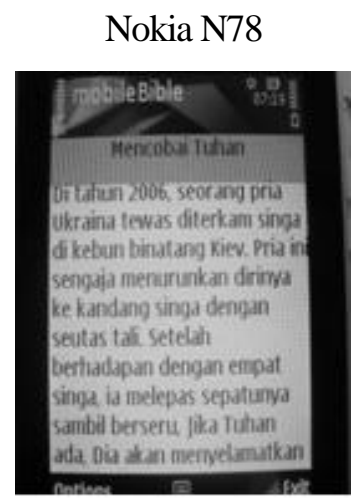

Sony Ericsson K800
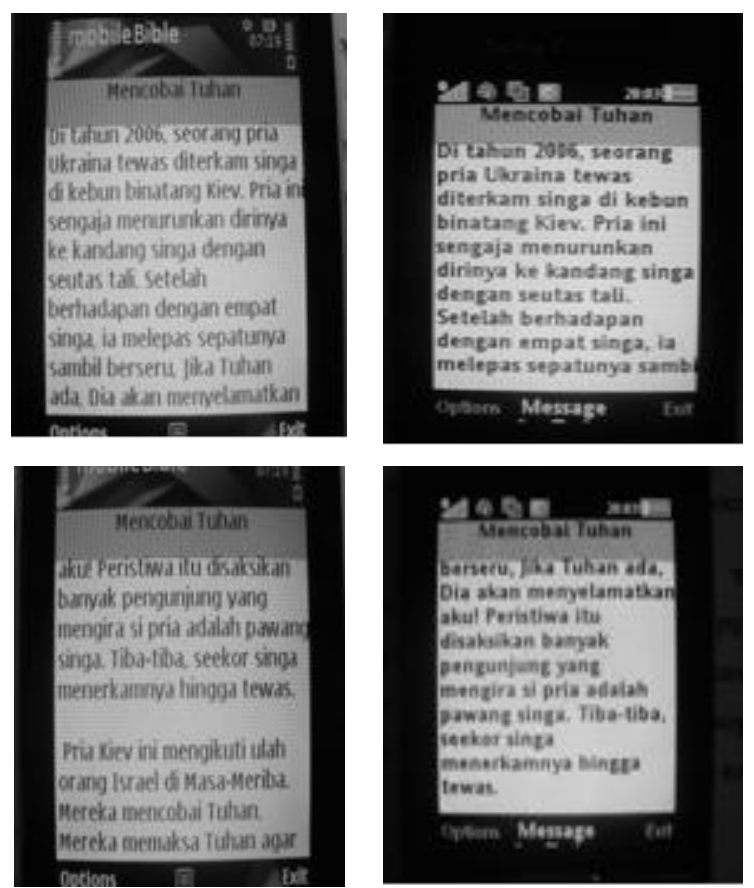

Gambar 10. Pengujian Tampilan Renungan Harian pada Nokia N78 dan Sony Ericson K800

Gambar 10 menunjukkan aplikasi renungan harian dapat dijalankan dengan baik baik pada Nokia N78 maupun Sony Erricson w910i, dan Sony Erricson k800.

- Pengujian Permindahan (Goto) Ayat

Nokia N 78
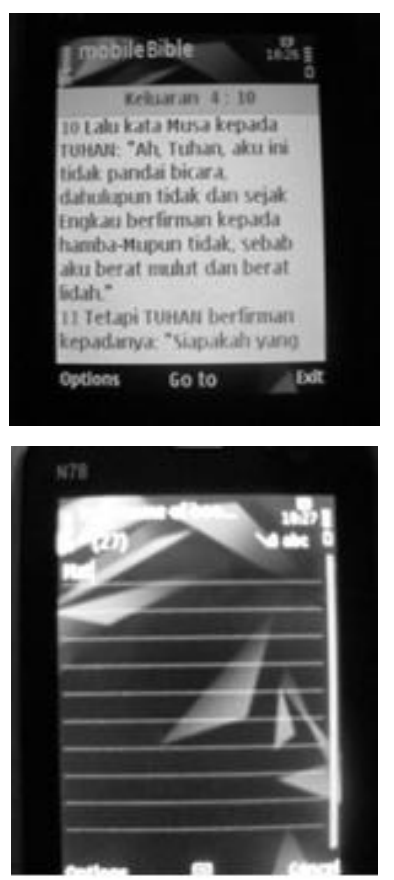

Sony Ericsson K800
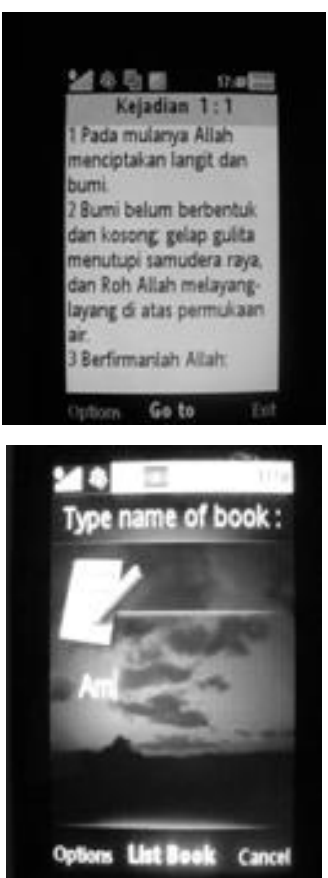
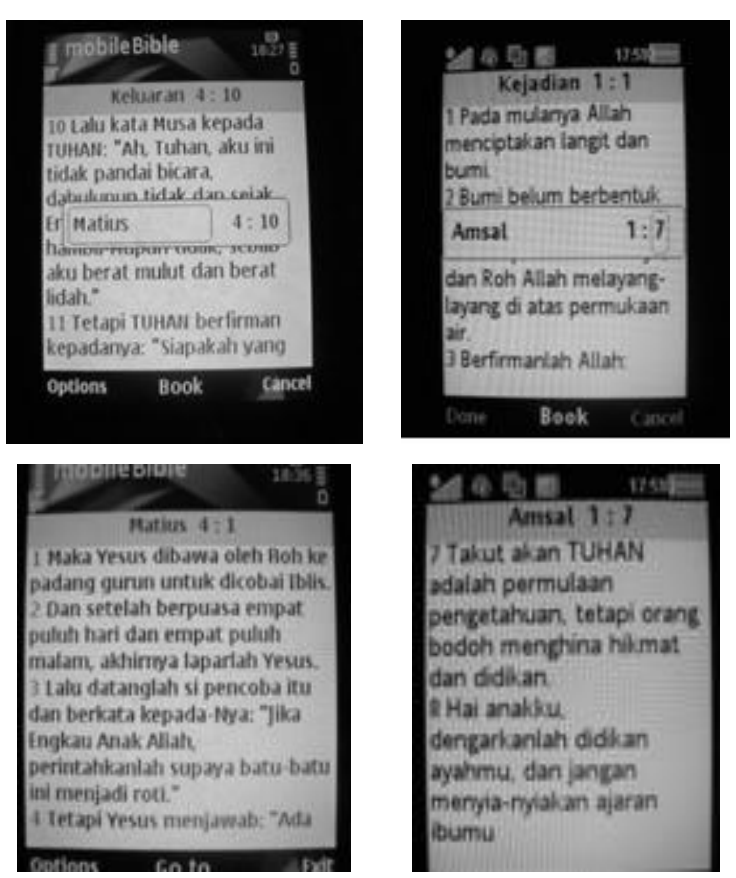

Gambar 11. Pengujian Tampilan Goto pada Nokia N78 dan Sony Ericson K800

Gambar 11 menunjukkan bahwa proses goto dapat dilakukan dengan baik pada ketiga ponsel tersebut. Proses pertama yang dilakukan user mengetikkan nama kitab pada sutu text area. Nama kitab yang ditulis tidak perlu ditulis lengkap cukup sebagian saja. Misalkan kitab yang dituju adalah Yesaya, maka dengan mengetikan "Yes" saja, sistem dapat mengerti bahwa kitab yang dimaksud adalah kitab Yesaya. Setelah kitab ditentukan, maka selanjutnya user dapat mengubah nilai pasal dan ayat yang sesuai dengan pasal dan ayat yang ingin dituju.

\section{KESIMPULAN}

Kesimpulan yang dapat diambil dari penelitian ini adalah sebagai berikut:

- Hasil pengujian aplikasi dapat berjalan dengan baik pada emulator maupun pada ponsel yang diuji cobakan.

- Pembatasan hak akses yang dilakukan oleh Java ME pada aplikasi untuk membaca file database alkitab yang berada diluar aplikasi menyebabkan ukuran aplikasi menjadi besar.

- Record store dapat menyimpan ayat-ayat yang bookmark, dan seeting terakhir yang dilakukan user.

- Adanya tambahan beberapa fitur yang tersedia pada aplikasi. Fitur tersebut antara lain memberikan highlight pada ayat, memberikan note yang akan mempermudah user untuk mencari content pada Alkitab berdasakan inputan user. 
- Pembuatan advanced search masih sebatas search matching biasa, proses selanjutnya dapat mengembangkan algoritma untuk menghitung bobot relasi antara ayat dengan inputan user yang berbasiskan server dengan menggunakan koneksi GPRS.

- Untuk perkembangan aplikasi bible yang berbasiskan Java ME dapat menggunakan library graphics seperti J2ME Polish, LWUIT ataupun J4ME untuk desain yang lebih bagus.

- Pembuatan file khusus untuk aplikasi bible pada Java ME yang lebih kecil sehingga ukuran file aplikasi tidak terlalu besar.

\section{DAFTAR PUSTAKA}

1. Keogh, J., 2003, J2ME: The Complete Reference, MC Graw-Hill.

2. Knudsen, J. and Li, S., 2006, Beginning J2ME: From Novice to Professional Third Edition. Apress.

3. Peranginangin, K., 2006, Aplikasi Web dengan PHP dan MySQL. Yogyakarta: Penerbit ANDI.

4. Raharjo, B., Heryanto, I., dan Haryono, A., 2007, Tuntunan Pemrograman Java untuk Handphone. Bandung: Informatika. 